\title{
Spatial distribution of fiddler crabs (genus Uca) in a tropical mangrove of northeast Brazil
}

\author{
LUIS ERNESTO ARRUDA BEZERRA ${ }^{1,2}$, CAROLINA BRAGA DIAS ${ }^{1,3}$, \\ GIVANILDO XIMENES SANTANA ${ }^{1}$ and HELENA MATTHEWS-CASCON ${ }^{1,4}$ \\ ${ }^{1}$ Pós-graduação em Ciências Marinhas Tropicais, Instituto de Ciências do Mar (LABOMAR), Universidade Federal do \\ Ceará, Fortaleza, Ceará, Brazil. E-mail: luiseab@gmail.com \\ ${ }^{2}$ Current address: Programa de Pós-Graduacão em Oceanografia, Departamento de Oceanografia, Universidade Federal de \\ Pernambuco, Avda Arquitetura, s/n, Cidade Universitária, 50790-540, Recife, Brazil. \\ ${ }^{3}$ Laboratório de Geologia e Geomorfologia Costeira e Oceânica, Universidade Estadual do Ceará, Fortaleza, Ceará, Brazil. \\ ${ }^{4}$ Departmento de Biologia, Universidade Federal do Ceará, Campus do Pici, Fortaleza, Ceará, Brazil.
}

\begin{abstract}
SUMMARY: The influence of abiotic factors on the spatial distribution of the fiddler crabs Uca leptodactyla, U. maracoani, $U$. rapax and $U$. thayeri was studied in a tropical mangrove of northeast Brazil. Eight transects were delimited in a mangrove area of the Pacoti River. On each transect, three $0.25 \mathrm{~m}^{2}$ squares were sampled during spring low tide periods from September 2003 to August 2004. The sediment of the squares at each transect was analysed for grain size, organic matter and humidity. Morphology of the second maxilliped was studied considering the number of spoon-tipped setae to help explain the ecological distribution of the species. U. leptodactyla and U. rapax were found living in medium sand, U. thayeri was collected in fine and very fine sand, while $U$. maracoani was found living in very fine sand. U. leptodactyla showed a negative correlation with organic matter and humidity while $U$. thayeri showed a positive correlations for both factors. U. maracoani and U. rapax were not correlated with organic matter or humidity. The analysis of the second maxilliped revealed that U. leptodactyla and U. rapax show a high quantity of spoon-tipped setae while $U$. maracoani and $U$. thayeri show a greater quantity of plumose setae.
\end{abstract}

Keywords: fiddler crab, spatial distribution, abiotic factors, second maxiliped analysis, tropical mangrove, northeast Brazil.

RESUMEN: DiSTRIBUCIÓN ESPACIAL DE CANGREJOS DEL GÉNERO UCA EN UN MANGLE TROPICAL EN EL NORDESTE DE BRASIL. La influencia de los factores abióticos sobre la distribución espacial de los cangrejos Uca leptodactyla, U. maracoani, U. rapax y $U$. thayeri fue estudiada en un mangle tropical en el Nordeste de Brasil. Se muestrearon mensualmente con tres cuadrantes $\left(0.25 \mathrm{~m}^{2}\right)$ en ocho áreas diferentes (transectos) de lo Mangle del Río Pacoti entre septiembre de 2003 y agosto de 2004. Las propiedades físicas del sedimento, i.e., textura, contenido orgánico y humedad también fueron evaluadas en cada cuadrante. La morfología del segundo maxilipedio se estudió considerado el número de setas con punta de cuchara para explicar la distribución ecológica de las especies. U. leptodactyla y $U$. rapax fueron encontrados en los sedimentos gruesos, mientras $U$. thayeri y $U$. maracoani fueron encontrados en los sedimentos lodosos. La abundancia de U. leptodactyla mostró una correlación negativa con el contenido orgánico y la humedad mientras U. thayeri mostró una correlación positiva con ambos factores. La abundancia de U. rapax y U. maracoani no estuvo correlacionada con la materia orgánica y humedad. El análisis del segundo maxilipedio reveló que $U$. leptodactyla y $U$. rapax presentan una cantidad alta de setas con punta de cuchara mientras $U$. maracoani y $U$. thayeri presentaron una cantidad mayor de setas plumosas.

Palabras clave: género Uca, distribución espacial, factores abióticos, análisis del segundo maxilipedio, manglar tropical, Nordeste de Brasil.

\section{INTRODUCTION}

Fiddler crabs, $U c a$, constitute one of the most characteristic groups of animals associated with intertidal shores, in particular with mangrove forests
(Crane, 1975). Though fiddler crabs are the most common and abundant faunal components of the mangroves, little attention has been directed at understanding factors that influence their local distribution and abundance in tropical habitats. 
Components of the environment believed to play a major role in the distribution of fiddler crabs are vegetation, substratum, food, salinity, tidal exposure and presence of other animals (Aspey, 1978; Icely and Jones, 1978; Rabalais and Cameron, 1985; EwaOboho, 1993; Thurman, 1998; Nobbs, 2003; Ribeiro et al., 2005; César et al., 2005).

Among the substratum characteristics, organic matter and water content, salinity, temperature and granulometric composition of sediments play an important role in fiddler crab distribution in mangrove forests (Frith and Brunenmeister, 1980; EwaOboho, 1993; Reinsel and Rittschof, 1995; Mounton and Felder, 1996).

Specialised as detritivores, different species of the genus $U c a$ are known to be morphologically and behaviourally specialised for handling particles of a certain size of substratum and food (Crane, 1975). In the $U c a$ feeding process, the minor chela passes material into the bucal cavity where the food to be ingested is selected by the mouth parts. In this process, the crab takes a single grain of sand into the bucal cavity, where adhering organic matter is scoured off and the cleaned grain rejected (Miller, 1961). The second maxilliped is particularly important in the separation process and has a great variety of specialised bristles (Maitland, 1990).

These bristles have become known as spoontipped setae, mainly through the descriptive work of Crane $(1941,1943)$. There are a great number of spoon-tipped setae in sand dwelling species, while crabs living in muddy habitats have an abundance of plumose setae on the second maxilliped (Crane, 1975). Altevogt (1957) observed that the spoontipped hairs aided in the elimination of coarse particles from the bucal cavity. Therefore, the characteristics of the second maxilliped exhibits the associations between crabs and sediment grains.

Nowadays, there are about 97 species of $U c a$ in the tropical and temperate climates throughout the world (Rosenberg, 2001). Eight species of Uca have been recorded in the tropical mangroves of northeast Brazil (Melo, 1996): U. burgersi Holthuis, 1967; U. cumulanta Crane, 1943; U. leptodactyla Rathbun, 1898; U. maracoani (Latreille, 1802-1803); U. mordax (Smith, 1870); U. rapax (Smith, 1870); U. thayeri Rathbun, 1900 and U. vocator (Herbst, 1804).

Although these species are very common in the tropical mangroves of northeast Brazil, the factors that may influence their distribution have not yet been investigated. We investigate the sediment char- acteristics that could influence the spatial distribution of four species of fiddler crabs (U. leptodactyla, U. maracoani, U. rapax, and U. thayeri) found in the tropical mangrove of Pacoti River (northeast Brazil). The morphology of the second maxilliped was studied considering the number of spoon-tipped setae to help explain the ecological distribution of the species.

\section{MATERIALS AND METHODS}

\section{Study area}

Sampling took place at Pacoti River Mangrove, Ceará State, northeast Brazil (343'02"S, 38³2'35”W) (Fig. 1). Tides are semidiurnal, with maximum tidal amplitude of about $3.1 \mathrm{~m}$ and minimum tidal amplitude of $0.9 \mathrm{~m}$. The climate is tropical, with an average yearly temperature of $27^{\circ} \mathrm{C}$ (Freire, 1989). The mangrove vegetation of this area (Miranda et al., 1988) is dominated by Avicennia schaueriana Stapf and Leechman, Avicennia germinans Linnaeus, Laguncularia racemosa Gaerth and Rhizophora mangle Linnaeus.

\section{Sampling and laboratory analyses}

Eight transects were delimited in a mangrove area of the Pacoti River, comprising an area of $1.2 \mathrm{~km}^{2}$. On each transect, three $50 \times 50 \mathrm{~cm}$ squares were sampled during diurnal spring tide periods from September 2003 to August 2004. Monthly, two transects were selected at random and visited. The squares were located along the transects, square 1 being at the edge of the mangrove vegetation, square

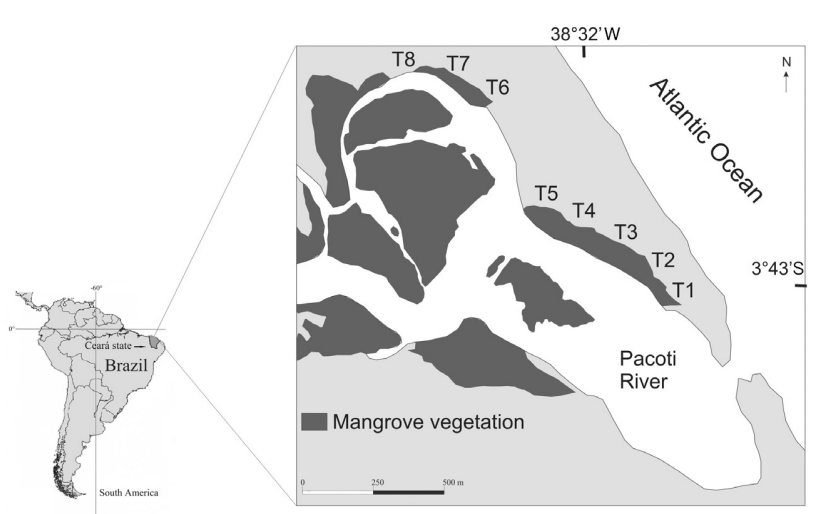

Fig. 1. - Map indicating the sampling area at Pacoti River mangrove, Ceará state, northeast Brazil, with location of sampling transects $\mathrm{T} 1$ to $\mathrm{T} 8$. 
2 in the middle of the mangrove and square 3 close to the margin of the river or on the mud flat when present. The squares were excavated with a corer to a depth of $30 \mathrm{~cm}$ and at the Uca maracoani site, because this species excavate deep burrows, they were excavated to a depth of $70 \mathrm{~cm}$. Collected crabs were bagged, labelled and preserved in $70 \%$ ethanol for further analysis. In the laboratory, specimens were identified and the number of crabs for each sample was recorded.

At each square, sediment samples (about $30 \mathrm{~cm}$ deep) were obtained. The sedimentology was only done once during the study period. The texture of sediments was measured according to Suguio (1973). The humidity was measured by weighing the sample before and after drying in an oven $\left(60^{\circ} \mathrm{C} / 48 \mathrm{~h}\right)$. The organic matter content was quantified by ash-free dry weighing (AFDW) according to Jeffery et al. (1992). For both humidity and organic matter, the average values of three samples at each portion of the transects was calculated, as well as the standard deviation. The software GRANULS (developed by Universidade Federal Fluminense, Rio de Janeiro, Brazil) was used to supply the statistical parameters and the granulometric classification of the samples. The average classification given by GRANULS is calculated considering all the kinds of sand in the sediment, and not just the most abundant kind of sand (simple frequency) in the sample.

The topographic profile of the transects was carried out using "Total Station" (Topcom company, model GTS 229).

\section{Morphology of second maxilliped}

Ten second maxillipeds of each species collected at different sites of the study area were carefully removed and observed to determine the presence or absence of spoon-tipped setae. The maxillipeds were observed under a stereomicroscope (Nikon SMZ 1000) equipped with a digital camera (Nikon Coolpix 4500).

\section{Statistical methods}

The log-likehood test $(G$-test $)$ was used to determine the preference of fiddlers by grain size of substratum (Zar, 1984). Spearman's rank correlation was used to relate the abundance of fiddler crabs with organic matter, humidity, and species among themselves (Zar, 1984).

\section{RESULTS}

\section{Sedimentology}

The edges in almost all transects were composed predominantly of medium sand, except in transects 4 and 5, where they were composed of fine sand. The middle parts of the transects were composed of medium sand in transects 1 and 8, fine sand in transects 2 , 3 and 7 and very fine sand in transects 4,5 and 6 . The portions close to the margin of the river were composed of fine sand in transects $1,4,5$ and 7 and of medium sand in transects 2, 3 and 8. Transect 6 was the only one that had an open mud flat composed of very fine sand. A dense mangrove vegetation (mainly Rhizophora mangle) was present in transects 1-7, while transect 8 was characterised by the absence of vegetation. Figure 2 shows a schematic topographic profile of the transects as well as the average granulometric classification of sediments at each portion of the transect given by GRANULS.

The average values of organic matter at the edge, in the middle and close to the margin were $2.89 \pm 0.78,7.67 \pm 8.70$ and $3.19 \pm 1.87 \%$, respectively. The highest values of organic matter content of sediments were found in portions composed of fine and very fine sand in the middle of transect 7 $(27.31 \pm 2.27 \%)$, transect $3(10.7 \pm 0.25 \%)$ and transect $4(10.53 \pm 0.07 \%)$, while the lowest values were found in regions composed of medium sand at the edge and in the middle of transect $8(0.60 \pm 0.15$ and $0.77 \pm 0.01 \%$, respectively) and close to the margin of transect $2(0.83 \pm 0.007 \%)$ and transect 3 $(0.34 \pm 0.007 \%)$.

With respect to the water content in the sediment, the average values for each portion of the transects were $22.71 \pm 1.77 \%$ at the edge, $38.68 \pm 16.2 \%$ in the middle and $25.93 \pm 8.87 \%$ close to the margin. Higher values were found in vegetated areas composed of fine and very fine sand in the middle of transect $4(58.8 \pm 1.22 \%)$, transect $3(58.2 \pm 2.87 \%)$ and transect $2(57.9 \pm 1.89 \%)$, while lower values were found in portions composed of medium sand close to the margin of transect $3(14.9 \pm 2.08 \%)$, in the middle of transect $1(20.1 \pm 2.24 \%)$ and at the edge of transect $2(20.3 \pm 1.67 \%)$.

\section{Spatial distribution}

A total of 678 fiddler crabs were sampled throughout the year in the transects, with 468 U. lep- 
$\mathrm{T} 1$

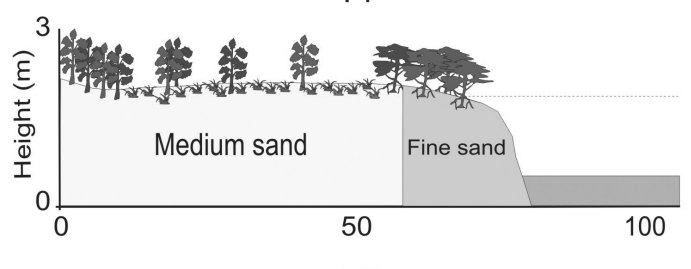

T2

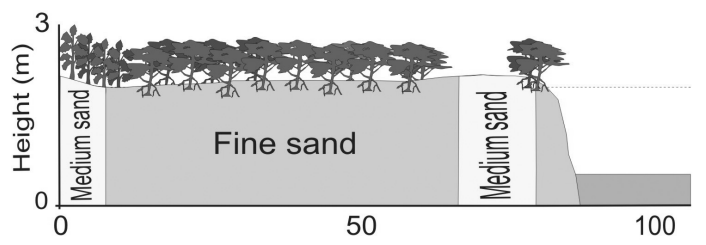

T3

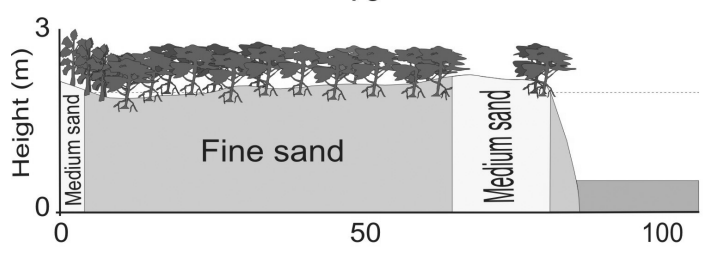

$\mathrm{T} 4$

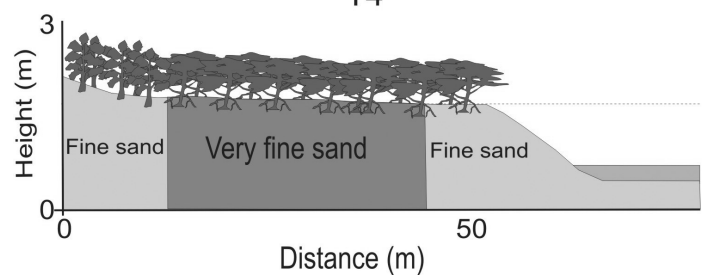

T5
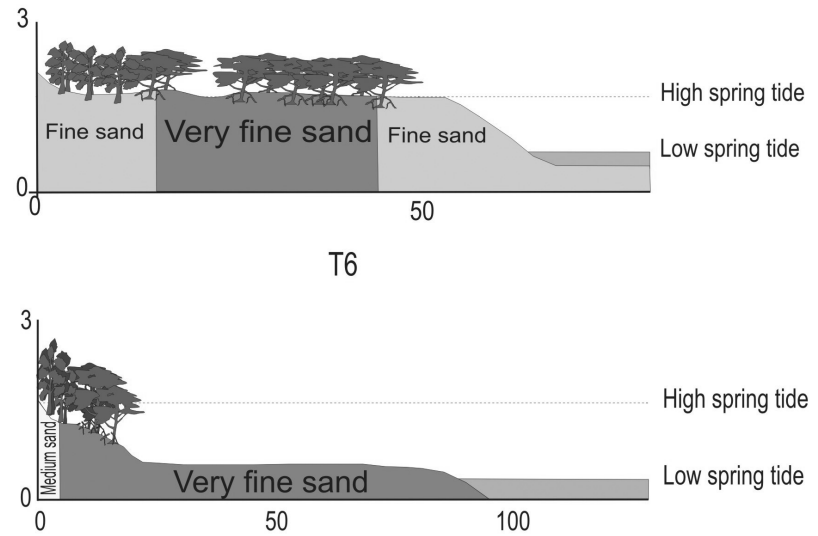

T7

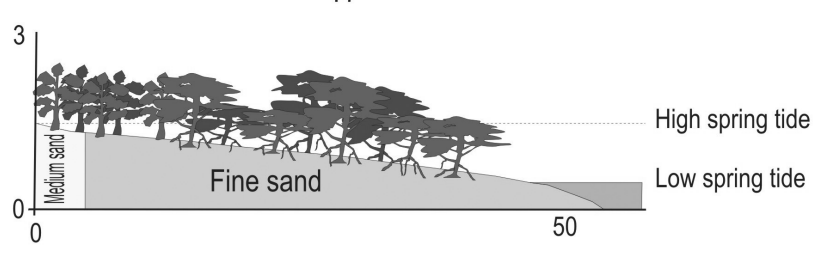

T8

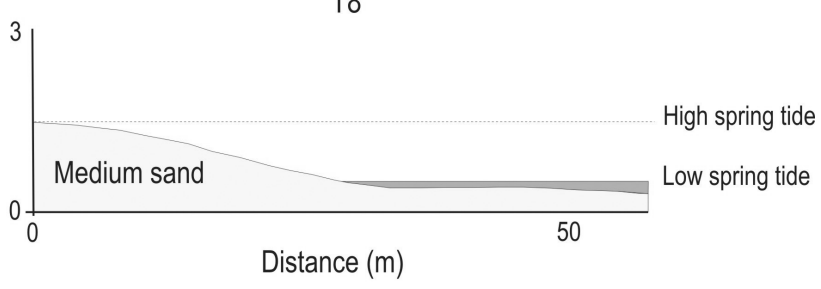

Fig. 2. - Schematic topographic profiles of transects T1 to T8 sampled at Pacoti River mangrove, northeast Brazil.

todactyla, $50 \mathrm{U}$. rapax, $119 \mathrm{U}$. thayeri and $41 \mathrm{U}$. maracoani. $U$. leptodactyla and $U$. rapax being found living at the edge of the mangrove. However, $U$. leptodactyla was collected close to the margin of transects 2 and 3 and in the middle of transect $8 . U$. thayeri was found in vegetated areas of all the transects, except in transect 8 , while $U$. maracoani was captured only in square 3 of transect 6 , an extensive open mud flat exposed during spring low tides.

TABLE 1. - Spearman's rank correlation among organic matter $(\mathrm{OM})$ and humidity of substratum and Uca species collected at Pacoti River mangrove, northeast Brazil. N=24.

\begin{tabular}{lrrr}
\hline & $\mathrm{R}$ & $\mathrm{T}(\mathrm{N}-2)$ & $p$ - level \\
\hline OM x U.leptodactyla & -0.50 & -2.72 & 0.01 \\
OM x U. rapax & 0.25 & 1.23 & 0.22 \\
OM x U. thayeri & 0.36 & 1.85 & 0.04 \\
OM x U. maracoani & -0.07 & -0.35 & 0.72 \\
Humidity x U. leptodactyla & -0.63 & 3.90 & $<0.01$ \\
Humidity x U. rapax & -0.23 & 1.13 & 0.26 \\
Humidity x U. thayeri & 0.59 & 3.48 & $<0.01$ \\
Humidity x U. maracoani & -0.07 & -0.35 & 0.72 \\
\end{tabular}

Figure 3 shows the overall frequency distribution of the species along the transects.

The spatial distribution did not show homogeneity along the transects. U. leptodactyla $(\mathrm{G}=351.8$, $\mathrm{DF}=3, p<0.001)$ and $U . \operatorname{rapax}(\mathrm{G}=28.73, \mathrm{DF}=3$, $p<0.001)$ were found on medium sand. $U$. thayeri was found in squares formed by fine and very fine sand $(\mathrm{G}=166.9, \mathrm{DF}=3, p<0.001)$ and $U$. maracoani was found living in the substrates composed by very fine sand $(\mathrm{G}=63.98, \mathrm{DF}=3, p<0.001)$.

Spearman's rank correlation between each species and the organic matter and water content of the sediment is presented in Table 1. U. leptodactyla showed a negative correlation for organic matter and humidity, while $U$. thayeri showed positive correlations for both factors. U. rapax and U. maracoani were not correlated with organic matter and humidity.

Table 2 shows the Spearman's rank correlation of abundance among the four species. U. leptodactyla showed a positive correlation with all other species except $U$. thayeri. On the other hand, U. thayeri 

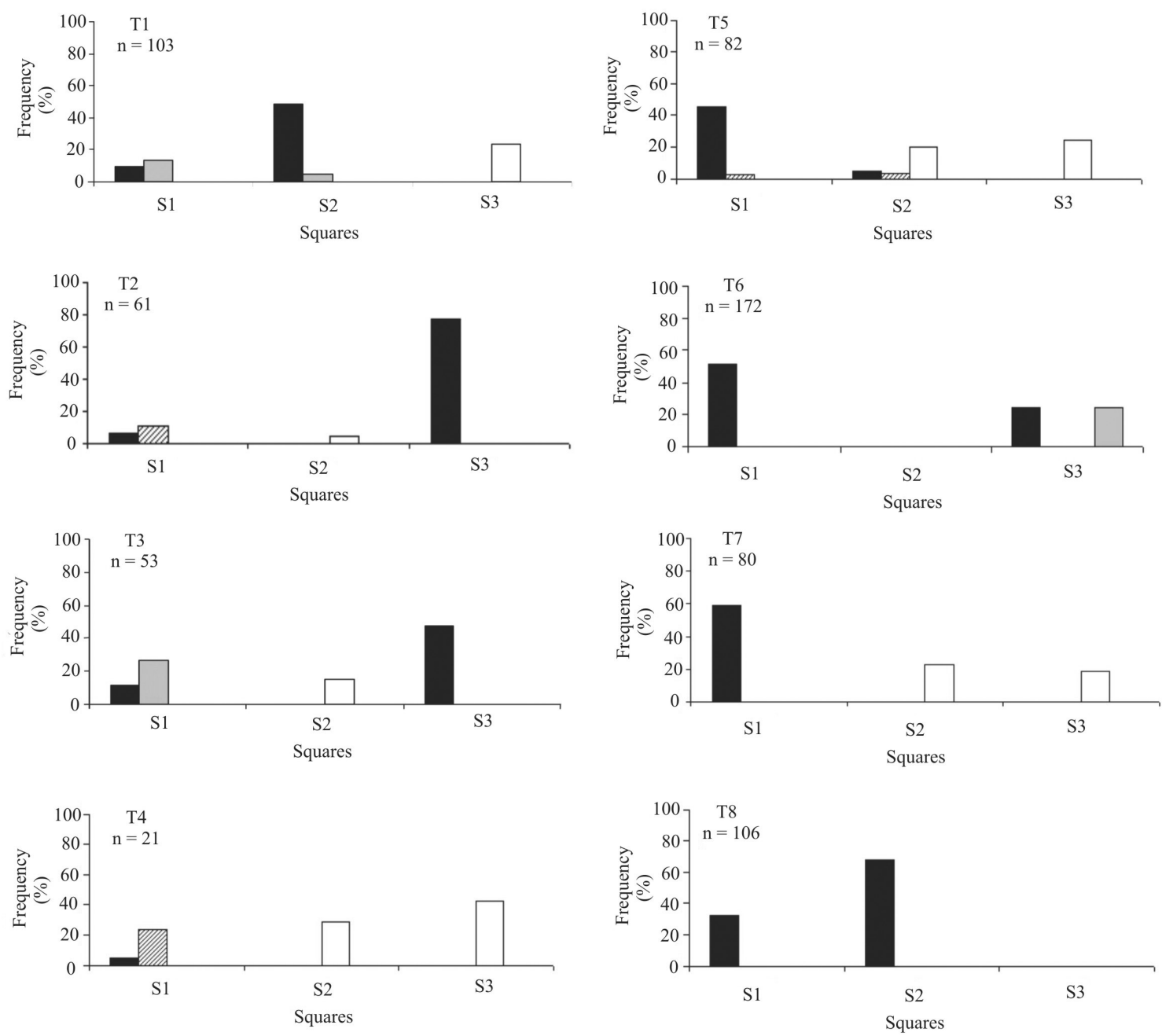

Fig. 3. - Overall frequency distribution of Uca species collected at Pacoti River mangrove, northeast Brazil, in the squares at each transect sampled. Black bars: U. leptodactyla, white bars: U. thayeri, hatched bars: U. rapax, grey bar: U. maracoani. Square 1 (S1): Edge of the mangrove vegetation; Square 2 (S2): Middle of the mangrove; Square 3 (S3): Close to the margin/open mud flat. T: Transects; n: Number of individuals.

showed negative correlations with the other three species. There was no correlation between $U$. maracoani and U. rapax.

\section{Morphology of second maxilliped}

The second maxilliped analysis showed that $U$. leptodactyla and $U$. rapax had a high number of spoon-tipped setae, while in U. thayeri and U. mara-

TABLE 2. - Spearman's rank correlation among Uca species collected at Pacoti River mangrove, northeast Brazil. * $p<0.05$, ** $p<0.25, * * * p<0.001,{ }^{\mathrm{ns}} p>0.05 . \mathrm{N}=24$.

\begin{tabular}{lccc}
\hline & U. leptodactyla & U. rapax & U. thayeri \\
U. rapax & $0.224^{*}$ & - & - \\
U. thayeri & $-0.690^{* * *}$ & $-0.309^{* *}$ & - \\
U. maracoani & $0.203^{*}$ & $-0.131^{\mathrm{ns}}$ & $-0.156^{*}$ \\
\hline
\end{tabular}

coani they occurred in small numbers. Both $U$. thayeri and $U$. maracoani presented a greater quantity of plumose setae when compared to $U$. leptodactyla and $U$. rapax (Fig. 4).

\section{DISCUSSION}

The distribution of crustacean decapods has been studied in relation to many environmental factors. The salinity and the features of the substratum are the most important factors that can influence the spatial distribution of a great number of species (Frusher et al., 1994), particularly fiddler crabs (MacIntosh, 1989).

On the coast of Mexico, sediment grain size is the main factor affecting the spatial distribution of fiddler crabs, with $U$. leptodactyla and $U$. rapax 

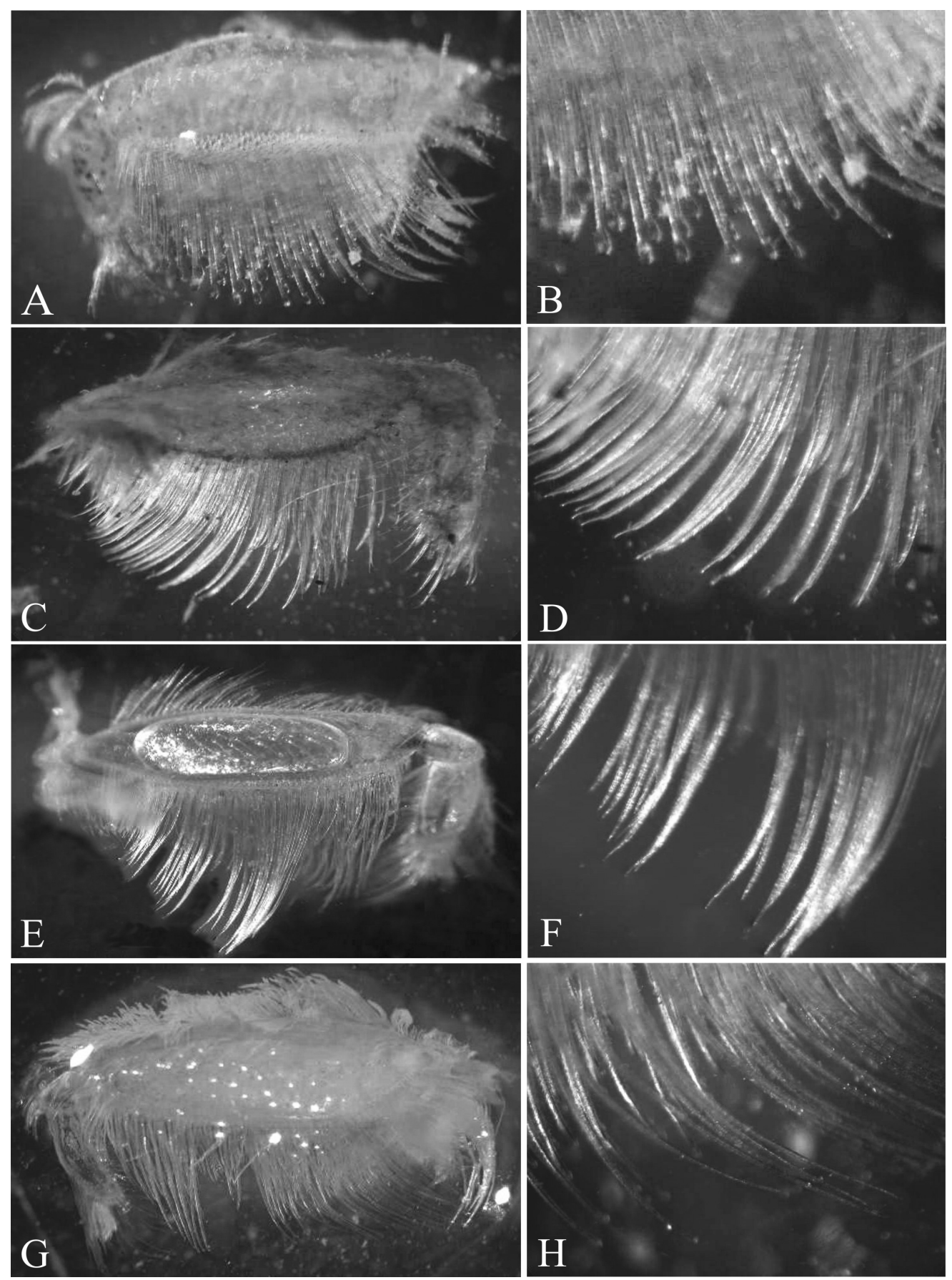

Fig. 4. - Dorsal view of the second maxilliped. A) U. leptodactyla; B) Detail of the setae. Maxilliped width: 2 mm. C) U. rapax; D) Detail of the setae. Maxilliped width: $5 \mathrm{~mm}$. E) U. thayeri; F) Detail of the setae. Maxilliped width: $8 \mathrm{~mm}$. G) U. maracoani; H) Detail of the setae. Maxilliped width: $10 \mathrm{~mm}$

showing a close relation for coarse sediments, while $U$. thayeri shows a higher affinity for muddy sediments (Thurman II, 1987). Similar associations were recorded by Costa (2000) for U. leptodactyla, $U$. rapax and $U$. thayeri in a subtropical mangrove of southeast Brazil. According to Holthuis (1959) $U$. maracoani can be found living in open mud flats, without vegetation.
$U$. leptodactyla and U. rapax were found living in sunny areas composed of medium sand at the edge of the mangrove, coinciding with Coelho (1965) and Warner (1969). U. thayeri was recorded only in shaded areas composed of fine sand and very fine sand, while $U$. maracoani inhabited open mud flats composed of very fine sediments, coinciding with Crane (1975) and Melo (1996). 
Recently, Koch et al. (2005) studying the spatial distribution and population dynamics of four species of fiddler crabs in North Brazil mangrove found that $U$. rapax was restricted to the high intertidal forest, while $U$. maracoani was mostly restricted to the sunny mud banks of larger creeks in the mid- and low intertidal zones.

With respect to organic matter and water content of sediments, Costa (2000) found positive correlations with organic matter and water content for $U$. thayeri, while $U$. leptodactyla showed negative correlations with organic matter. Aciole et al. (2000) and Santos (2001) found U. leptodactyla living in areas with lower quantities of organic matter. With respect to $U$. rapax, Costa (2000) found positive correlations with organic matter content and negative correlations with humidity, while U. maracoani was recorded by Coelho and Coelho-Filho (1993) living in areas with high quantities of organic matter and humidity. Therefore, in the Pacoti river mangrove the fiddler crabs correlations with organic matter and water content of sediments coincide with previous results described in the literature. However, Koch et al. (2005) found $U$. rapax and U. maracoani living in areas with low organic matter content in a tropical mangrove of northern Brazil.

The positive correlation between $U$. leptodactyla and $U$. rapax showed that these species can be found co-habiting in the same area on the mangrove forest and have similar needs for similar resources (Costa, 2000). The absence of $U$. rapax in areas where $U$. leptodactyla was abundant (transect 8 and squares 3 in transect 2 and 3) can be explained by the lower organic matter content. U. rapax had a positive correlation with organic matter and would not tolerate areas with a low value.

$U$. thayeri and $U$. maracoani were found to exclude each other along the mangrove (negative correlations). Nevertheless, these species have similar needs in relation to grain size, organic matter and water content of sediment, but $U$. thayeri prefers vegetated habitats, while $U$. maracoani prefers open ones. Some males of $U c a$ species wave their enlarged claw during courtship (Crane, 1975) and $U$. maracoani employs sophisticated visual signals in the courtship behaviour (Crane, 1975). On the other hand, $U$. thayeri employs simple wave signals (Crane, 1975). Thus, reduction in visibility could be responsible for the avoidance of vegetated areas by $U$. maracoani.
Similarly, Nobbs (2003), studying three species of fiddler crabs (U. elegans George and Jones, 1982, U. signata (Hess, 1865) and U. flamula Crane, 1975) in an Australian mangrove, found that U. elegans avoided vegetated areas while $U$. flamula and $U$. signata preferred vegetated habitats. Compared to the other species, U. elegans employs visual signals more often and may avoid vegetated habitats because they hinder its visibility.

Koch et al. (2005) pointed out that in the north Brazilian mangrove the sunny mud banks of larger creeks were completely dominated by U. maracoani, probably due to its greater tolerance to high temperatures. Oxygen consumption measured in water at different temperatures by Koch (1999) revealed that $\mathrm{O}_{2}$-consumption of $U$. maracoani increased up to a temperature of $35^{\circ} \mathrm{C}$, while all other species showed highly reduced $\mathrm{O}_{2}$-consumption at temperatures above 30 to $32^{\circ} \mathrm{C}$, indicating physiological stress due to overheating (Koch et al., 2005).

The ability of an organism to obtain nutrition from its environment is one of the basic requisites for survival and is thus a factor governing the distribution of animals (Miller, 1961). Fiddler crabs that are specialised in sorting food from habitats with low organic content can sometimes be found in habitats with high organic contents, but species that are specialised in obtaining food in muddy areas with high organic contents cannot live in areas with coarse sand and low organic content (Jones, 1984).

Modifications of the second maxilliped setae have been recorded in fiddler crabs as an adaptation to inhabiting different kinds of substratum (Miller, 1961; Icely and Jones, 1978; Thurman II, 1987; Maitland, 1990; Mounton and Felder, 1996). These modifications are important in the ecology of $U c a$ species and can be used to explain their distribution in the mangrove forests (Jones, 1984).

According to Maitland (1990), fiddler crabs that sort foods on muddy habitats have plumose setae in the second maxilliped merus, and fiddler crabs that live in coarse sand have spoon-tipped setae on the second maxilliped. In this study, $U$. leptodactyla and $U$. rapax were found in areas with medium sand, while U. thayeri and U. maracoani were found in muddy habitats. Fewer setae are spoon-tipped on the second maxilliped of the muddy fiddler crabs $U$. thayeri and $U$. maracoani than on those of the sand-inhabiting species $U$. leptodactyla and U. rapax. 


\section{ACKNOWLEDGEMENTS}

This study was completed by L.E.A. Bezerra to partially fulfil the requirements for a Master degree in Tropical Marine Science at the Federal University of Ceará. The authors would like to thanks CAPES ("Coordenação de Aperfeiçoamento de Pessoal de Nível Superior") for a master fellowship to L.E.A. Bezerra and the students T.O. Falcão and P.H. Sousa for their assistance with sedimentological analysis. Special thanks to Dr. T.M.C. Lotufo for the assistance with statistical procedures and for comments on the thesis, to Dr. P.A. Coelho for comments on the thesis, to Dr. P. Cascon, who provided useful insights and revised the English language, and to Dr. G. Bigatti for revising the Spanish abstract. The authors are also very grateful to the Scientific Editor Dr. F. Maynou and to two anonymous referees for their comments, which improved the manuscript.

\section{REFERENCES}

Aciole, S.D.G., E.C. Sousa and T.C.S. Calado. - 2000. Aspectos bioecológicos de Uca cumulanta Crane, 1943 e Uca leptodactyla Rathbun, 1898 (Crustacea: Decapoda: Ocypodidade) do complexo estuarino-lagunar Mundaú/Manguaba - Maceió, Estado de Alagoas. Bol. Estud. Cienc. Mar, 79: 79-100.

Altevogt, R. - 1957. Untersuchungen zur Biologie, Ökologie und Physiologie indischer Winkerkrabben. Z. Morph. Ökol. Tiere, 46(1): 1-110.

Aspey, W.P. - 1978. Fiddler crab behavioral ecology: burrow density in Uca pugnax (Smith) and Uca pugilator (Box) (Decapoda, Brachyura). Crustaceana, 34: 235-244.

César, I.I., L.C. Armendáriz and R.C. Becerra. - 2005. Bioecology of the fiddler crab Uca uruguayensis and the burrowing crab Chasmagnathus granulatus (Decapoda, Brachyura) in the Refugio de Vida Silvestre Bahía Samborombón, Argentina. Hydrobiologia, 545: 273-248.

Coelho, P.A. and P.A. Coelho-Filho. - 1993. Chave para identificação dos crustáceos decápodos braquiúros encontrados nos biótopos de água salobra do litoral oriental do Nordeste do Brasil. B. Técn. Cient. CEPENE, 1: 29-56.

Coelho, P.A. - 1965. Os crustáceos decápodos de alguns manguezais pernambucanos. Trabs. Oceanog. Univ. Fed. PE, 7/8: 71-90.

Costa, T.M. - 2000. Ecologia de caranguejos semiterrestres do gênero Uca (Crustacea, Decapoda, Ocypodiae) de uma área de manguezal, em Ubatuba (SP). Ph. D. thesis, Univ. Estadual Paulista.

Crane, J. - 1941. Eastern Pacific Expedition of the New York Zoological Society. XXVI. Crabs of the genus Uca from the west coast of Central America. Zoologica, 26: 145-208.

Crane, J. - 1943. Display, breeding and relationship of the fiddler crabs (Brachyura, genus $U c a$ ) in the northeastern United States. Zoologica, 28: 217-223.

Crane, J. - 1975. Fiddler crabs of the world. Ocypodidae: genus Uca. Princeton University Press, Princeton.

Ewa-Oboho, I.O. - 1993. Substratum preference of the tropical estuarine crabs, Uca tangeri Eydoux (Ocypodidae) and Ocypode cursor Linne (Ocypodidae). Hydrobiologia, 271: 119-127.

Freire, G.S.S. - 1989. Etude hydrologique et sédimentologique de l'estuaire du Rio Pacoti (Fortaleza - Ceará - Brésil). Ph. D. thesis, Univ. Nantes.

Frith, D.W. and S. Brunenmeister. - 1980. Ecological and popula- tion studies of fiddler crabs (Ocypodidae, genus $U c a$ ) on a mangrove shore at Phuket Island, Western Peninsular Thailand. Crustaceana, 39: 157-183.

Frusher, S.D., R.L. Giddings and T.J. Smith III. - 1994. Distribution and abundance of Grapsid crabs (Grapsidae) in a mangrove estuary: effects of sediments characteristics, salinity, tolerance and osmoregulatory ability. Estuaries, 17: 647-654.

Holthuis, L.B. - 1959. The crustacea decapoda of Suriname (Duth Guiana). Zool. Verhand., 44: 1-296.

Icely, J.D. and D.A. Jones. - 1978. Factors affecting the distribution of the genus Uca (Crustacea: Ocypodidae) on an East African shore. Est. Coast. Shelf Mar. Sci., 6: 315-325.

Jeffery, G.H., J. Bassett, J. Meridham, R.C. Deney and A.I. Vogel. - 1992. Análise química quantitativa. Guanabra Koogan, Rio de Janeiro.

Jones, D.A. - 1984. Crabs of the mangal ecosystem. In F.D. Por and I. Dor (eds.), Hidrobiology of the mangal, pp. 89-109. W. Junk Publishers, Boston.

Koch, V. - 1999. Epibenthic production and energy flow in the Caeté Mangrove Estuary, North Brazil. Ph. D. thesis, Univ. Bremen.

Koch, V., M. Wolff and K. Diele. - 2005. Comparative population dynamics of four fiddler crabs (Ocypodidae, genus Uca) from a North Brazilian mangrove ecosystem. Mar. Ecol. Prog. Ser., 291: 177-188.

MacIntosh, D.J. - 1989. The ecology and physiology of decapods of mangrove swamps. P. Zool. Soc. Lond., 59: 325-341.

Maitland, D.P. - 1990. Feeding and mouthpart morphology in the semaphore crab Heloecius cordiformis (Decapoda: Brachyura: Ocypodidae). Mar. Biol., 105: 287-296.

Melo, G.A.S. - 1996. Manual de identificação dos Brachyura (Caranguejos e siris) do litoral brasileiro. Plêiade, São Paulo.

Miller, D.C. - 1961. The feeding mechanism of fiddler crabs, with ecological considerations of feeding adaptations. Zoologica, 46: 89-101.

Miranda, P.T.C., M.L.R. Martins and Z.M.L. Soares. - 1988. Levantamento e quantificação das áreas de manguezais no Estado do Ceará (Brasil) através de sensoriamento remoto. Proc. V Simp. Brasileiro Sensoriamento Remoto, Natal, Brazil, 90-94.

Mounton, E. C. Jr. and D.L. Felder. - 1996. Burrow distribution and population estimates for the fiddler crabs Uca spinicarpa and Uca longisignalis in a Gulf of Mexico salt marsh. Estuaries, 19: 51-61.

Nobbs, M. - 2003. Effects of vegetation differ among three species of fiddler crabs (Uca spp.). J. Exp. Mar. Biol. Ecol., 284: 41-50.

Rabalais, N.N. and J.N. Cameron. - 1985. Physiological and morphological adaptations of adults Uca subcylindrica to semi-arid environments. Biol. Bull., 168: 135-146.

Reinsel, K.A. and D. Rittschof. - 1995. Environmental regulation of foraging in the sand fiddler crab Uca pugilator (Bosc, 1802). J. Exp. Mar. Biol. Ecol., 187: 269-287.

Ribeiro, P.D., O.O. Iribarne and P. Daleo. - 2005. The relative importance of substratum and recruitment in determining the spatial distribution of the fiddler crab Uca uruguayensis Nobili. J. Exp. Mar. Biol. Ecol., 314: 99-111.

Rosenberg, M.S. - 2001. The systematics and taxonomy of fiddler crabs: A phylogeny of the genus Uca. J. Crust. Biol., 21: 839-869.

Santos, M.A.C. dos. - 2001. Crustáceos decápodos do mediolitoral do estuário do Rio Paripe - Itamaracá, Pernambuco - Brasil. $\mathrm{Ph}$. D. thesis, Univ. Federal de Pernambuco.

Suguio, K. - 1973. Introdução a sedimentologia. Edgard Blucher, New York.

Thurman II, C.L. - 1987. Fiddler crabs (genus Uca) of eastern Mexico (Decapoda, Brachyura, Ocypodidae). Crustaceana, 53: 95-105.

Thurman, C.L. - 1998. Osmorregulation by six species of fiddler crabs $(U c a)$ from the Mississipi delta area in the northern Gulf of Mexico. J. Exp. Mar. Biol. Ecol., 291: 233-252.

Warner, G.F. - 1969. The occurrence and distribution of crabs in a Jamaican mangrove swamp. J. Anim. Ecol., 38: 379-387.

Zar, J.H. - 1984. Biostatistical analysis. Prentice-Hall, Inc., New Jersey.

Received January 5, 2006. Accepted July 4, 2006.

Scient. ed.: F. Maynou.

Published online November 21, 2006. 